\title{
Intercropping maize and cowpea cultivars: I. Green-grain yield ${ }^{1}$
}

\author{
Consorciação de cultivares de milho e feijão-caupi: I. Rendimentos de grãos verdes
}

\author{
Marcos Antônio Leite da Silva ${ }^{2}$, Paulo Sérgio Lima e Silva ${ }^{3 *}$, Vianney Reinaldo de Oliveira ${ }^{3}$, Roberto Pequeno de \\ Sousa $^{3}$ and Paulo Igor Barbosa e Silva ${ }^{3}$
}

\begin{abstract}
Green ears of maize are much appreciated all over Brazil and reach higher prices than dry grain. This also occurs with green cowpea grain, which is much appreciated in the north and northeast of the country. The aim of this study was to identify maize and cowpea cultivars that can be grown as monocrops or intercrops to produce green grain in the state of Pará (PA). An experiment was carried out in a randomized block design with six replications in Marabá, PA. Monocrops of traditional varieties of the cowpea ('Corujinha' and 'Sempre Verde') and the maize cultivars ('AG 1051' and 'AL Bandeirante'), and four alternating, intercropped rows of a combination of the varieties and cultivars were evaluated. The 'AG 1051' cultivar was more productive than the 'AL Bandeirante' cultivar, as both a monocrop and an intercrop. The cowpea cultivars showed a similar performance under both systems of cultivation. There was no interaction between the maize cultivars and cowpea cultivars. The monocrops were superior to the intercrops for green-ear, green-pod and green-grain yield. Considering the land equivalent ratio, if the aim is to produce green pods, intercropping is only beneficial in the AG 1051 + Corujnha combination. If the aim is for green-grain yield in the cowpea, intercropping is more advantageous when the 'AG 1051' cultivar is combined with any cowpea cultivar. The intercrop including the 'AL Bandeirante' cultivar is only beneficial with the 'Corujinha' cultivar, and if the aim is to market unhusked, green ears of maize.
\end{abstract}

Key words: Zea mays. Vigna unguiculata. Green maize. Green beans. Land equivalent ratio.

RESUMO - Espigas verdes de milho são muito apreciadas em todo o Brasil e alcançam preços superiores aos dos grãos secos. Fato semelhante ocorre com os grãos verdes de feijão-caupi, que são muito apreciados nas regiões Norte e Nordeste desse país. Objetivou-se identificar cultivares de milho e de feijão-caupi que possam ser cultivadas no estado do Pará, em monocultivo ou em consórcio, para produção de grãos verdes. Um experimento foi realizado no delineamento de blocos casualizados com seis repetições, em Marabá-PA. Monocultivos de variedades tradicionais de feijão-caupi (Corujinha e Sempre Verde) e de cultivares de milho (AG 1051 e AL Bandeirante) e quatro consórcios, em fileiras alternadas, das combinações das variedades e cultivares foram avaliados. A cultivar AG 1051 foi mais produtiva do que a cultivar AL Bandeirante, em monocultivo e em consorciação. As cultivares de feijão-caupi apresentaram desempenhos semelhantes nos dois sistemas de cultivo. Não houve interação cultivares de milho x cultivares de feijão-caupi. Os monocultivos foram superiores aos consórcios, quanto aos rendimentos de espigas verdes e de vagens e grãos verdes. Considerando-se a eficiência do uso da terra, se a exploração visar a produção de vagens verdes, a consorciação somente será proveitosa na combinação AG 1051 + Corujinha. Se a exploração visar o rendimento de grãos verdes de feijão-caupi, a consorciação será vantajosa com a cultivar AG 1051 for combinada com qualquer cultivar de feijão-caupi. O consórcio envolvendo a cultivar AL Bandeirante somente será proveitoso com a cultivar Corujinha e se a exploração do milho visar espigas verdes empalhadas comercializáveis.

Palavras-chave: Zea mays. Vigna unguiculata. Milho verde. Feijão verde. Uso eficiente da terra.

\footnotetext{
DOI: $10.5935 / 1806-6690.20200014$

*Author for correspondence

Received for publication 14/12/2018; approved on 10/07/2019

'Trabalho extraído da Tese do primeiro autor apresentada ao Programa de Pós-Graduação em Fitotecnia, Departamento de Ciências Agronômicas e Florestais, Universidade Federal Rural do Semi-Árido; trabalho realizado com o apoio do CNPq

${ }^{2}$ Instituto Federal de Educação, Ciência e Tecnologia do Pará/IFPA, Campus Rural de Marabá, Marabá-PA, Brasil, marcos.leite@ifpa.edu.br (ORCID ID 0000-0002-1482-9771)

${ }^{3}$ Departamento de Ciências Agronômicas e Florestais, Universidade Federal Rural do Semi-Árido/UFERSA, Mossoró-RN, Brasil, paulosergio@ ufersa.edu.br (ORCID ID 0000-0002-4465-6517), vianney.reinaldo@hotmail.com (ORCID ID 0000-0002-3853-7247), rpequeno@ufersa.edu.br (ORCID ID 0000-0002-9103-8981), pauloigorbs@ gmail.com (ORCID ID 0000-0001-8609-8835)
} 


\section{INTRODUCTION}

Cultivation of the cowpea [Vigna unguiculata (L.) Walp.], previously limited almost exclusively to the northeast of Brazil, is expanding to the region of the Cerrado, and to the north, northeast and mid-west of the country, where it is included in production managements as an off-season crop, after soybean and rice, and, in some places, as the main crop (FREIRE FILHO, 2011). Maize (Zea mays L.) is grown in all regions of Brazil, and is only surpassed in terms of cultivated area by the soybean (MÔRO; FRITSCHE-NETO, 2015).

One of the characteristics of cowpea and maize production systems in Brazil is the exploitation of each crop to produce both green and dried grain. Green cowpea grain has a water content of around $60 \%$, while green maize grain has a water content of around 70 to $80 \%$. Green cowpea grain is much appreciated in the north and northeast of Brazil, and reaches higher prices than those of the dry grain. This also occurs with green ears of maize, which are consumed throughout Brazil.

Green maize and cowpea grain are produced from monocrops and intercrops. There is a growing interest in grass-legume intercropping for the following reasons: higher and more-stable yields and economic margins than those obtained under monocropping, and a better use of resources by the intercrops (BEDOUSSAC et al., 2015).

Studies on evaluating cultivars for green-grain production in the cowpea (ANDRADE et al., 2010; BASTOS et al., 2012; SILVA et al., 2013) and in maize (ALMEIDA et al., 2005; CASTRO; SILVA; CARDOSO, 2013) under monocropping, have shown that there are differences between cultivars in terms of green-grain yield. Intercropping for green-grain production in maize or the cowpea has been evaluated by few authors (GUEDES et al., 2010; SANTOS et al., 2014; SILVA, 2001), and such evaluations have shown that some combinations of cultivar are more advantageous than others; they have also demonstrated that under intercropping, the yield of both crops is lower than under monocropping, but that some maize-cowpea combinations allow a better use of resources for production (greater land equivalent ratio).

As such, there is an interest in identifying maize and cowpea cultivars that can be grown in the state of Pará, as monocrops or intercrops, to produce green grain. In the state, the regions where the two crops are exploited are generally characterized by subsistence farming and family farmers using low levels of technology (ALVES et al., 2017; COUTINHO et al., 2014; SOUZA et al., 2002; SOUZA et al., 2017).

The aim of the present study was to identify maize and cowpea cultivars that can be exploited as monocrops and intercrops to produce green grain.

\section{MATERIAL AND METHODS}

The experiment was carried out from January to May 2015 on the Rural Marabá Campus of the Federal Institute of Education, Science and Technology of ParáIFPA (05'34'14.8' $\mathrm{S}$ and $49^{\circ} 06^{\prime} 02.3^{\prime}$ ' W, at an altitude of $95 \mathrm{~m}), 38 \mathrm{~km}$ from the town of Marabá.

In the Köppen-Geiger classification, the climate in the region lies on the transition from type AW to type Am. The climate is considered Tropical (Subtype Aw), with both a wet and a dry season (rainy summer and dry winter). The wettest period extends from December to April, and the driest from June to October. March has the highest rainfall (377 $\mathrm{mm})$ and August the lowest $(12 \mathrm{~mm})$. The average air temperature is $28^{\circ} \mathrm{C}$, with the maximum mean temperature around $32.7^{\circ} \mathrm{C}$ and a minimum mean temperature of 23.3 ${ }^{\circ} \mathrm{C}$. The mean monthly relative humidity ranges from 76 to $86 \%$, while the annual mean is $82 \%$. Total mean annual insolation is 2263 hours (ALMEIDA, 2007). During the experimental period (January to May 2015), the average air temperature ranged from 24.5 to $25.6{ }^{\circ} \mathrm{C}$, the total radiation and rainfall were $67 \mathrm{mj} \mathrm{m}^{-2}$ day $^{-1}$ and $989 \mathrm{~mm}$ respectively, and the relative humidity ranged from 87 to $98 \%$. The data were obtained from the Onça Puma Weather Station of the Vale Technological Institute. The Onça Puma Station is located in the town of Ourilândia do Norte, PA (06³1'46”' S 5103'33”' W, 259m), 394 km from Marabá - PA (TAVARES et al., 2018).

According to the Brazilian System of Soil Classification (EMBRAPA, 2013), the soil in the experimental area is classified as a Dystrophic Red-Yellow Latosol, with a sandy-clay texture and red coloration, deep, friable and highly erodible. Ten samples of the experimental soil were taken at random from a depth of approximately 0 to $25 \mathrm{~cm}$, which were then combined to form a composite sample and submitted to chemical analysis. The results of this analysis were as follows: $\mathrm{pH}$ $=5.6\left(\mathrm{H}_{2} \mathrm{O}\right) ; \mathrm{OM}=1.8 \mathrm{~g} \mathrm{~kg}^{-1} ; \mathrm{P}=3.67 \mathrm{mg} \mathrm{dm}^{-3} ; \mathrm{K}^{+}=54.7$ $\mathrm{mg} \mathrm{dm}{ }^{-3} ; \mathrm{Ca}^{2+}=1.43 \mathrm{cmol}_{\mathrm{c}} \mathrm{dm}^{-3} ; \mathrm{Mg}^{2+}=0.50 \mathrm{cmol}_{\mathrm{c}} \mathrm{dm}^{-3}$; $\mathrm{Al}^{3+}=0.02 \mathrm{cmol}_{\mathrm{c}} \mathrm{dm}^{-3} ; \mathrm{H}+\mathrm{Al}=3.03 \mathrm{cmol}_{\mathrm{c}} \mathrm{dm}^{-3}$.

The experiment was carried out in a randomized complete-block design with six replications and eight treatments. The treatments were the result of two maize monocrops (the 'AG 1051' and 'AL Bandeirante' cultivars), two cowpea monocrops (the 'Corujinha' and 'Sempre Verde' traditional varieties) and four intercrops. The intercrops were obtained by combining the two maize cultivars with the two varieties of cowpea. Six treatments were therefore evaluated for each crop. For the intercrops, the maize and cowpea occupied alternating rows. 'Corujinha' and 'Sempre Verde' were chosen from among the varieties most used by family farmers in settlements neighboring the IFPA Campus. Both are Creole varieties 
of indeterminate growth, and are used in the region as monocrops and intercrops to produce both green and dry grain. The 'AG 1051' cultivar is a double hybrid with a semi-early cycle, recommended for "normal" and off-season crops in the South, Midwest, Southeast and Northeast, and the in state of Rondônia, (CRUZ; PEREIRA FILHO, 2006). 'AL Bandeirantes' is a open-pollinated variety with a semi-early cycle, used under conventional cropping systems as a normal and off-season crop (CRUZ; PEREIRA FILHO, 2006).

Each plot was $6.0 \mathrm{~m}$ in length, with the width varying according to the number of planted rows. This number differed and depended on the cropping system, and had the purpose of avoiding the border effect in the cowpea where plots of this crop came between two plots of maize. The monocrops of maize and cowpea were evaluated in three and five rows respectively, while the intercrops were evaluated in four rows. The working area was considered that occupied by the central row of the monocrops, and by the two central rows of the intercrops. Under both systems of cultivation, the plants from the end holes of each central row were considered borders and not included when collecting data.

The experiment was carried out under rainfed conditions in an area that received $2 \mathrm{t} \mathrm{ha}^{-1}$ limestone and had been cultivated with maize during the 2012/1013 and 2013/2014 seasons. The soil was harrowed twice, and received $40 \mathrm{~kg} \mathrm{~N}, 120 \mathrm{~kg} \mathrm{P}_{2} \mathrm{O}_{5}$ and $40 \mathrm{~kg}$ of $\mathrm{K}_{2} \mathrm{O}$ per hectare. In the cowpea, base fertilization included $10 \mathrm{~kg} \mathrm{~N}, 120 \mathrm{~kg}$ $\mathrm{P}_{2} \mathrm{O}_{5}$ and $40 \mathrm{~kg} \mathrm{~K} \mathrm{O}_{2}$ per hectare. In the maize and cowpea, ammonium sulfate, simple superphosphate and potassium chloride were used as sources of nitrogen, phosphorus and potassium respectively. In both crops, the fertilizers were applied by hand below and to the side of the planting furrows. Weeds were controlled by hoeing 20 and 40 days after sowing. Cover fertilizer (ammonium sulfate) was applied after each weeding, using $40 \mathrm{~kg} \mathrm{~N} \mathrm{ha}^{-1}$ for the maize and $10 \mathrm{~kg} \mathrm{~N} \mathrm{ha}^{-1}$ for the cowpea.

Both crops were sown by hand on February 4, 2015 , using four seeds per hole. The spacing was 1.0 $\mathrm{x} 0.4 \mathrm{~m}$ for the maize, and $1.0 \times 1.0 \mathrm{~m}$ for the cowpea, in both the monocrops and the intercrops. Twenty days after sowing, the crops were thinned, leaving two plants per hole. As such, after thinning, the planting density of the monocropped maize and cowpea was 50,000 and 20,000 plants ha ${ }^{-1}$ respectively; the respective densities of the intercropped maize and cowpea were 25,000 and 10,000 plants $\mathrm{ha}^{-1}$.

The cowpea crop was sprayed twice, 18 and 25 days after planting (DAP), with $0.42 \%$ neem oil (Azadiracta indica A. Juss) to control aphids (Aphis spp. Linnaeus, 1758), the cucurbit beetle (Diabrotica speciosa
Germar) and whitefly (Bemisia argentifolii Bellows; Perring). In the maize crop, colonies of the maize-leaf aphid (Rhopalosiphum maidis Fitchi, 1856) were seen; these were controlled by spraying twice with $0.42 \%$ neem oil, at 37 and 43 DAP.

In plots where green-grain yield was evaluated, six harvests were made, at 61, 65, 71, 77, 82 and 87 days after planting. The harvests were made when grains showed a moisture content of around $60 \%$. Cowpea yield was measured from the weights of the pods and green grain. The number of pods per plant (based on the total pods collected in the plot), the number of grains per pod (based on ten pods from the third collection) and the 100-grain weight (based on five grain samples from pods from the third collection) were also evaluated.

The green maize was harvested 70, 72 and 74 days after planting, when the grain had a moisture content of between 70 and $80 \%$. Green-maize yield was evaluated from the total number and weight of the ears, and the number and weight of marketable husked and unhusked ears. Marketable husked ears were considered those of suitable appearance and with a length of $20 \mathrm{~cm}$ or more. Marketable unhusked ears were considered those whose health and grain production were suitable for marketing, and whose length was $17 \mathrm{~cm}$ or over (criteria used in the region).

To evaluate the forage potential of the green maize, two plants, taken at random from different holes after the final collection, were cut close to the ground, weighed and crushed in a forage maker. A $100 \mathrm{~g}$ sample was placed in a sterilizing and drying oven at $75{ }^{\circ} \mathrm{C}$ for three days to obtain the dry weight.

The advantage of intercropping over monocropping was evaluated using the land equivalent ratio (LER) defined by Mead and Willey (1980): LER $=\mathrm{LER}_{\mathrm{A}}+\mathrm{LER}_{\mathrm{B}} \cdot \mathrm{LER}_{\mathrm{A}}=\mathrm{A}_{\mathrm{i}} / \mathrm{A}_{\mathrm{m}}$ and $\mathrm{LER}_{\mathrm{B}}=\mathrm{B}_{\mathrm{i}} / \mathrm{B}_{\mathrm{m}}$, where $\mathrm{Ai}$ and $\mathrm{Bi}$ represent the yields of intercrops $\mathrm{A}$ and $B$ respectively, and $A_{m}$ and $B_{m}$ represent the respective yields of monocrops $A$ and $B$. The values for LER were calculated from the pod yield and green-grain yield in the cowpea, and from the yield (in terms of weight) of total and marketable husked and unhusked ears in the maize.

Analysis of variance of the data for the maize and cowpea grain was carried out using the Microsoft Excel (2010) software. In the maize crop, the five treatment degrees of freedom (2 monocrops +4 intercrops - 1) were broken down as follows: one degree for comparing monocrops vs. intercrops; one degree for comparing monocrops; one degree for comparing maize cultivars under intercropping, considering mean values in the cowpea cultivars; one degree for comparing maize cultivars under 
intercropping, considering mean values for each cowpea cultivar; and one degree for evaluating the existence of the maize cultivar $x$ cowpea cultivar interaction. In the cowpea crop, the degrees of freedom were similarly broken down, except for one degree for comparing cowpea varieties under intercropping, considering mean values in the maize cultivars, and one degree for comparing cowpea varieties under intercropping, considering mean values for each maize cultivar. Student's t-test was applied at 5\% probability to the mean values of the Land Equivalent Ratio to verify whether they were greater than 1.0 .

\section{RESULTS AND DISCUSSION}

For the total number of green ears of maize, the analysis of variance showed an effect from a comparison of the monocrops and intercrops only (Table 1). On average, the monocrops were superior to the intercrops (Table 2). The effects of the treatments on the number of marketable unhusked ears were similar to those of the treatments on the number of marketable husked ears (Table 1). There was no effect on these characteristics from a comparison of the maize cultivars within each of the cowpea cultivars or from their interaction. As a

Table 1 - Summary of the analysis of variance of the data for the number of green ears in monocropped maize cultivars and intercropped with cowpea cultivars ${ }^{1}$

\begin{tabular}{|c|c|c|c|c|}
\hline \multirow{3}{*}{ Source of variation } & \multirow{3}{*}{ Degrees of freedom } & \multicolumn{3}{|c|}{ Number of ears ha-1 } \\
\hline & & Total & Marketable unhusked & Marketable husked \\
\hline & & \multicolumn{3}{|c|}{ Mean square } \\
\hline Blocks & 5 & $5371856.3^{\mathrm{ns}}$ & $5279295.3^{\text {ns }}$ & $12091789.3^{\mathrm{ns}}$ \\
\hline Treatments & (5) & $1161329244.9 * *$ & $891959031.8 * *$ & $782128705.7 * *$ \\
\hline Monocrops & 1 & $7975590.8^{\mathrm{ns}}$ & $908941320.3 * *$ & $1498075840.3 * *$ \\
\hline Monocrops vs. Intercrops & 1 & $5788503406.1 * *$ & $3099350790.0 * *$ & $1872281425.7 * *$ \\
\hline Intercrops & (3) & $3389075.8^{\mathrm{ns}}$ & $150501016.3 * *$ & $180095420.8^{* *}$ \\
\hline $\begin{array}{l}\text { Intercropped maize cultivars (mean } \\
\text { values for the cowpea cultivars) }\end{array}$ & 1 & $5913315.4^{\mathrm{ns}}$ & $445714347.0 * *$ & $532578552.0 * *$ \\
\hline $\begin{array}{l}\text { Intercropped maize cultivars (mean } \\
\text { values for each cowpea cultivar) }\end{array}$ & 1 & $1174395.0^{\mathrm{ns}}$ & $3495303.4^{\mathrm{ns}}$ & $1812251.0^{\mathrm{ns}}$ \\
\hline Maize $\mathrm{x}$ cowpea interaction & 1 & $3079517.0^{\mathrm{ns}}$ & $2293398.4^{\mathrm{ns}}$ & $5895459.4^{\mathrm{ns}}$ \\
\hline Error & 25 & 9220671.1 & 10304166.4 & 14969866.2 \\
\hline
\end{tabular}

$1 \mathrm{~ns} ; * ; *$ : not significant; significant at $5 \%$ and significant at $1 \%$ probability respectively by F-test

Table 2 - Mean values for the number of green ears in monocropped maize cultivars and intercropped with cowpea cultivars ${ }^{1}$

\begin{tabular}{|c|c|c|c|c|}
\hline \multirow{2}{*}{ Comparison } & & \multicolumn{3}{|c|}{ Number of ears ha-1 } \\
\hline & & Total & Marketable unhusked & Marketable husked \\
\hline \multirow{2}{*}{ Monocrops } & AG 1051 & 54538 a & 49359 a & $45180 \mathrm{a}$ \\
\hline & AL Bandeirante & 52908 a & $31953 \mathrm{~b}$ & $22833 \mathrm{~b}$ \\
\hline \multirow{2}{*}{$\begin{array}{c}\text { Intercropped maize (mean values for } \\
\text { the cowpea cultivars) }\end{array}$} & AG 1051 & $27320 \mathrm{a}$ & $25282 \mathrm{a}$ & $23419 \mathrm{a}$ \\
\hline & AL Bandeirante & $26328 \mathrm{a}$ & $16663 \mathrm{~b}$ & $13998 \mathrm{~b}$ \\
\hline \multirow{2}{*}{$\begin{array}{c}\text { Intercropped maize (mean values for } \\
\text { each cowpea cultivar) }\end{array}$} & Corujinha & 27045 a & $21355 \mathrm{a}$ & 18983 a \\
\hline & Sempre Verde & $26603 \mathrm{a}$ & $20591 \mathrm{a}$ & $18434 \mathrm{a}$ \\
\hline \multirow{2}{*}{ Monocrops vs. Intercrops } & Monocrop & $53723 \mathrm{a}$ & $40656 \mathrm{a}$ & $34007 \mathrm{a}$ \\
\hline & Intercrop & $26824 \mathrm{~b}$ & 20973 b & $18708 \mathrm{~b}$ \\
\hline Coefficient of variation $(\%)$ & 8.5 & 15.1 & 16.3 & \\
\hline
\end{tabular}

${ }^{1}$ Mean values followed by the same letter in each comparison do not differ at $5 \%$ probability by F-test 
monocrop and as an intercrop, the 'AG 1051' cultivar was superior to 'AL Bandeirante' (Table 2). On average, the monocrops were superior to the intercrops (Table 2).

The effects of the treatments on total weight and on the weight of marketable husked and unhusked ears were similar (Table 3). That is, there was an effect from the monocropped and intercropped cultivars, and from the comparison of the monocrops with the intercrops. The 'AG 1051' cultivar was more productive than the 'AL Bandeirante' cultivar, both as a monocrop and intercrop (Table 4). Furthermore, the monocrops were better on average than the intercrops (Table 4). Several characteristics are responsible for the superiority of one cultivar over another in terms of yield. Characteristics of the root-system and shoots, as well as physiological characteristics, determine the differences in yield between cultivars (LYNCH, 2013; MI et al., 2010; QI et al., 2010). As such, suggesting causes for the superiority of the 'AG 1051 ' cultivar in relation to 'AL Bandeirante' is difficult.

The superiority of the monocrops in relation to the intercrops for all the characteristics used to evaluate greenear yield, must have been due mainly to the larger plant population used in the monocrops (50 thousand plants ha-1) compared to that adopted under intercropping ( 25 thousand plants $\mathrm{ha}^{-1}$ ). It is possible that the competition caused by the cowpea due to production factors (water, nutrients and

Table 3 - Summary of the analysis of variance of the data for green-ear weight in monocropped maize cultivars and intercropped with cowpea cultivars ${ }^{1}$

\begin{tabular}{|c|c|c|c|c|}
\hline \multirow{3}{*}{ Source of variation } & \multirow{3}{*}{ Degrees of freedom } & \multicolumn{3}{|c|}{ Ear weight $\left(\mathrm{kg} \mathrm{ha}^{-1}\right)$} \\
\hline & & Total & Marketable unhusked & Marketable husked \\
\hline & & \multicolumn{3}{|c|}{ Mean square } \\
\hline Blocks & 5 & $816221.4^{\mathrm{ns}}$ & $855655.5^{\mathrm{ns}}$ & $434193.2^{\text {ns }}$ \\
\hline Treatments & (5) & $72795664.9 * *$ & $77354594.3^{* *}$ & $32054456.8 * *$ \\
\hline Monocrops & 1 & $52250133.3^{* *}$ & $123123320.3 * *$ & $71638533.3 * *$ \\
\hline Monocrops vs. Intercrops & 1 & $280102890.9 * *$ & $193211929.4 * *$ & $61049408.4 * *$ \\
\hline Intercrops & (3) & $10541766.8^{* *}$ & $23479240.6^{* *}$ & $9194780.7^{* *}$ \\
\hline $\begin{array}{l}\text { Intercropped maize cultivars (mean } \\
\text { values for the cowpea cultivars) }\end{array}$ & 1 & $30172837.5^{* *}$ & $69298813.5^{* *}$ & $26964280.0 * *$ \\
\hline $\begin{array}{l}\text { Intercropped maize cultivars (mean } \\
\text { values for each cowpea cultivar) }\end{array}$ & 1 & $682762.7^{\mathrm{ns}}$ & $781204.2^{\mathrm{ns}}$ & $385827.0^{\mathrm{ns}}$ \\
\hline Maize $\mathrm{x}$ cowpea interaction & 1 & $769700.2^{\text {ns }}$ & $357704.2^{\mathrm{ns}}$ & $234235.0^{\mathrm{ns}}$ \\
\hline Error & 25 & 1068763.5 & 1254919.5 & 726994.6 \\
\hline
\end{tabular}

1ns; $* *$ : not significant; significant at $1 \%$ probability respectively by F-test

Table 4 - Mean values for green-ear weight in monocropped maize cultivars and intercropped with cowpea cultivars ${ }^{1}$

\begin{tabular}{ccccc}
\hline \multirow{2}{*}{ Comparison } & & \multicolumn{3}{c}{ Ear weight $\left(\mathrm{kg} \mathrm{ha}^{-1}\right)$} \\
\cline { 3 - 5 } Monocrops & AG 1051 & $14719 \mathrm{a}$ & $13915 \mathrm{a}$ & $8658 \mathrm{a}$ \\
& AL Badeirante & $10545 \mathrm{~b}$ & $7509 \mathrm{~b}$ & $3772 \mathrm{~b}$ \\
\hline \multirow{2}{*}{$\begin{array}{c}\text { Intercropped maize (mean values for } \\
\text { the cowpea cultivars) }\end{array}$} & AG 1051 & $7836 \mathrm{a}$ & $7497 \mathrm{a}$ & $4512 \mathrm{a}$ \\
\hline Intercropped maize (mean values for & AL Bandeirante & $5593 \mathrm{~b}$ & $4099 \mathrm{~b}$ & $2392 \mathrm{~b}$ \\
\hline each cowpea cultivar) & Sempre Verde & $6546 \mathrm{a}$ & $5978 \mathrm{a}$ & $3579 \mathrm{a}$ \\
\hline Monocrops vs. Intercrops & Monocrop & $12632 \mathrm{a}$ & $5617 \mathrm{a}$ & $3326 \mathrm{a}$ \\
\hline Coefficient of variation (\%) & Intercrop & $6715 \mathrm{~b}$ & $5798 \mathrm{~b}$ & $6215 \mathrm{a}$ \\
\hline
\end{tabular}

${ }^{1}$ Mean values followed by the same letter in each comparison do not differ at $5 \%$ probability by F-test 
light) also contributed to the reduction in maize yield in the intercrops. For a maize-soybean intercrop, Lv et al. (2014) found that below-ground competition was more relevant than above-ground competition. However, in the present study, it was seen that branches of the two cowpea cultivars "involved" the maize plants, which must have intensified the light competition. It should also be mentioned that the plants of the 'Corujinha' "involved" the maize plants more vigorously than did the 'Sempre Verde' cultivar.

In terms of pod yield and green-grain yield, the analysis of variance in the cowpea indicated an effect from a comparison of the monocrops with the intercrops only
(Table 5). On average, the monocrops were superior to the intercrops for both characteristics (Table 6). The superiority of the monocrops must have been due mainly to the larger population of monocrops (20 thousand plants ha-1) compared to that of the intercrops $(10,000$ plants ha-1 $)$. Competition exerted by the intercropped maize must also have reduced cowpea yield. Similar results have been seen by other authors (NDAKIDEMI; DAKORA, 2007).

The greater pod yield and green-grain yield in the monocrops were due to the higher number of pods, since the 100-grain weight and number of grains per pod were greater in the intercrops (Tables 7 and 8). Therefore, compensation occurred between the principal yield

Table 5 - Summary of the analysis of variance of the data for pod yield and green-grain yield in monocropped cowpea cultivars and intercropped with maize cultivars

\begin{tabular}{|c|c|c|c|}
\hline \multirow{3}{*}{ Source of variation } & \multirow{3}{*}{ Degrees of freedom } & \multicolumn{2}{|c|}{ Yield $\left(\mathrm{kg} \mathrm{ha}^{-1}\right)$} \\
\hline & & \multicolumn{2}{|c|}{ Mean square } \\
\hline & & Pods & Grain \\
\hline Blocks & 5 & $2849299.8^{\text {ns }}$ & $557296.3^{\text {ns }}$ \\
\hline Treatments & 5 & $6784695.7 * *$ & $1323139.0 *$ \\
\hline Monocrops & 1 & $1594323.0^{\mathrm{ns}}$ & $1239061.3^{\mathrm{ns}}$ \\
\hline Monocrops vs. Intercrops & 1 & $28332882.7 * *$ & $3778042.4^{* *}$ \\
\hline Intercrops & 3 & $1332090.9^{\text {ns }}$ & $532863.8^{\mathrm{ns}}$ \\
\hline $\begin{array}{c}\text { Intercropped cowpea (mean values for the maize } \\
\text { cultivars) }\end{array}$ & 1 & $506341.5^{\mathrm{ns}}$ & $448540.0^{\mathrm{ns}}$ \\
\hline $\begin{array}{c}\text { Intercropped cowpea (mean values for each maize } \\
\text { cultivar) }\end{array}$ & 1 & $1462240.7^{\mathrm{ns}}$ & $910651.0^{\mathrm{ns}}$ \\
\hline Cowpea $\mathrm{x}$ maize interaction & 1 & $2027690.7^{\mathrm{ns}}$ & $239400.4^{\mathrm{ns}}$ \\
\hline Error & 25 & 1107598.3 & 368854.6 \\
\hline
\end{tabular}

1 ns; *;** not significant; significant at $5 \%$ and significant at $1 \%$ probability respectively by F-test

Table 6 - Mean values for pod yield and green-grain yield in monocropped cowpea cultivars and intercropped with maize cultivars ${ }^{1}$

\begin{tabular}{|c|c|c|c|}
\hline \multirow{2}{*}{ Comparison } & & \multicolumn{2}{|c|}{ Yield $\left(\mathrm{kg} \mathrm{ha}^{-1}\right)$} \\
\hline & & Pods & Grain \\
\hline \multirow{2}{*}{ Monocrops } & Corujinha & $4749 \mathrm{a}$ & $2388 \mathrm{a}$ \\
\hline & Sempre Verde & $4020 \mathrm{a}$ & $1745 \mathrm{a}$ \\
\hline \multirow{2}{*}{$\begin{array}{c}\text { Intercropped cowpea (mean values for the maize } \\
\text { cultivars) }\end{array}$} & Corujinha & $2648 \mathrm{a}$ & $1516 \mathrm{a}$ \\
\hline & Sempre Verde & $2357 \mathrm{a}$ & $1242 \mathrm{a}$ \\
\hline \multirow{2}{*}{$\begin{array}{c}\text { Intercropped cowpea (mean values for each maize } \\
\text { cultivar) }\end{array}$} & AG 1051 & $2749 \mathrm{a}$ & $1574 \mathrm{a}$ \\
\hline & AL Bandeirante & $2256 \mathrm{a}$ & $1184 \mathrm{a}$ \\
\hline \multirow{2}{*}{ Monocrops vs. Intercrops } & Monocrop & $4384 \mathrm{a}$ & $2066 \mathrm{a}$ \\
\hline & Intercrop & $2502 \mathrm{~b}$ & $1379 \mathrm{~b}$ \\
\hline Coefficient of variation $(\%)$ & & 33.63 & 37.8 \\
\hline
\end{tabular}

${ }^{1}$ Mean values followed by the same letter in each comparison do not differ at $5 \%$ probability by F-test 
components for the pods and the green grain (number of pods per plant, number of grains per pod and grain weight). This compensation, which is common in many crops, occurs mainly under conditions of stress, such as those caused by competition with other cowpea plants (monocrops) or with other cowpea and maize plants (intercrops). As proposed by Adams (1967) for Phaseolus vulgaris L., the compensation seen in the present study is a result of the competition for metabolites, both organic and inorganic, by the three yield components.

The effect of the maize cultivar $\mathrm{x}$ cowpea cultivar interaction was not significant for the characteristics under evaluation (Tables 3, 5 and 7), demonstrating the similar behavior of the maize cultivars when intercropped with the cowpea cultivars, and vice versa. Similar results to those reported here, regarding the absence of the maize cultivar $x$ cowpea cultivar interaction, were seen by Silva (2001). However, other authors have found that late-cycle maize genotypes are negatively affected when intercropped (SANTOS et al., 2014).

The analysis of variance of the data for land equivalent ratio (LER) calculated based on green-pod yield in the cowpea and on green-maize yield, is shown in Table 9. The corresponding mean values are presented in

Table 7 - Summary of the analysis of variance of the data for the production components of green grain in monocropped cowpea cultivars and intercropped with maize cultivars

\begin{tabular}{|c|c|c|c|c|}
\hline \multirow[b]{2}{*}{ Source of variation } & \multirow{2}{*}{$\begin{array}{l}\text { Degrees of } \\
\text { freedom }\end{array}$} & \multicolumn{3}{|c|}{ Mean square } \\
\hline & & Number of pods ha' & $\begin{array}{l}\text { 100-grain weight } \\
(\mathrm{g})\end{array}$ & $\begin{array}{l}\text { Number of grains } \\
\text { pod }^{-1}\end{array}$ \\
\hline Blocks & 5 & $34108126602.1^{\text {ns }}$ & $6.6^{\mathrm{ns}}$ & $0.32^{\text {ns }}$ \\
\hline Treatments & 5 & $142008149513.2 * *$ & $41.7 * *$ & $4.45^{* *}$ \\
\hline Monocrops & 1 & $63515988108.0^{\mathrm{ns}}$ & $74.0 * *$ & $2.08 *$ \\
\hline Monocrops vs. Intercrops & 1 & $519860905278.1 * *$ & $16.1^{*}$ & $12.50 * *$ \\
\hline Intercrops & 3 & $42221284726.6^{\mathrm{ns}}$ & $39.5 * *$ & $2.56 * *$ \\
\hline $\begin{array}{c}\text { Intercropped cowpea (mean values for the } \\
\text { maize cultivars) }\end{array}$ & 1 & $66622816876.0^{\mathrm{ns}}$ & $113.5^{* *}$ & $6.00 * *$ \\
\hline $\begin{array}{c}\text { Intercropped cowpea (mean values for each } \\
\text { maize cultivar) }\end{array}$ & 1 & $36400411593.4^{\mathrm{ns}}$ & $4.9^{\mathrm{ns}}$ & $1.50 *$ \\
\hline Cowpea $\mathrm{x}$ maize interaction & 1 & $23640625710.4^{\mathrm{ns}}$ & $0.2^{\mathrm{ns}}$ & $0.17^{\mathrm{ns}}$ \\
\hline Error & 25 & 18901788430.5 & 2.8 & 0.28 \\
\hline
\end{tabular}

1 ns; *; not significant; significant at $5 \%$ and significant at $1 \%$ probability respectively by F-test

Table 8 - Mean values for the production components of green grain in monocropped cowpea cultivars and intercropped with maize cultivars $^{1}$

\begin{tabular}{|c|c|c|c|c|}
\hline Comparison & & $\begin{array}{l}\text { Number of pods } \\
\text { ha }^{-1}\end{array}$ & $\begin{array}{l}\text { 100-grain weight } \\
\text { (g) }\end{array}$ & $\begin{array}{l}\text { Number of grains } \\
\operatorname{pod}^{-1}\end{array}$ \\
\hline \multirow{2}{*}{ Monocrops } & Corujinha & $680625 \mathrm{a}$ & $22,1 \mathrm{~b}$ & $16 \mathrm{a}$ \\
\hline & Sempre Verde & $535119 \mathrm{a}$ & $27,1 \mathrm{a}$ & $15 \mathrm{~b}$ \\
\hline \multirow{2}{*}{$\begin{array}{c}\text { Intercropped cowpea (mean values for the } \\
\text { maize cultivars) }\end{array}$} & Corujinha & $405642 \mathrm{a}$ & $23,8 \mathrm{~b}$ & $17 \mathrm{a}$ \\
\hline & Sempre Verde & $300268 \mathrm{a}$ & $28,2 \mathrm{a}$ & $16 \mathrm{~b}$ \\
\hline \multirow{2}{*}{$\begin{array}{l}\text { Intercropped cowpea (mean values for each } \\
\text { maize cultivar) }\end{array}$} & AG 1051 & $391900 \mathrm{a}$ & $25,6 \mathrm{a}$ & $17 \mathrm{a}$ \\
\hline & AL Bandeirante & $314011 \mathrm{a}$ & $26,5 \mathrm{a}$ & $17 \mathrm{a}$ \\
\hline \multirow{2}{*}{ Monocrops vs. Intercrops } & Monocrop & $607872 \mathrm{a}$ & $24,6 \mathrm{~b}$ & $16 \mathrm{~b}$ \\
\hline & Intercrop & $352955 \mathrm{~b}$ & $26,0 \mathrm{a}$ & $17 \mathrm{a}$ \\
\hline Coefficient of variation $(\%)$ & & 31.39 & 6.5 & 3.2 \\
\hline
\end{tabular}

${ }^{1}$ Mean values followed by the same letter in each comparison do not differ at $5 \%$ probability by F-test 
Table 10. Although all LER values were greater than one, only those seen in the 'AG 1051' and 'Corujinha' intercrop were significant (Table 10), i.e. intercropping is only beneficial if the aim is to produce green pods and if the most-productive maize cultivar (AG 1051) is intercropped with the 'Corujinha' cultivar of the cowpea.

The analysis of variance of the data for land equivalent ratio (LER), calculated based on green-grain yield in the cowpea and on green-maize yield, is shown in Table 11. For this type of yield, intercropping continues to be beneficial if the most-productive maize cultivar (AG 1051) is intercropped with the two cowpea cultivars
(Table 12). The intercrop involving the 'AL Bandeirante' maize cultivar is only beneficial when intercropped with the 'Corujinha' cultivar, and when the aim is to exploit the maize for marketable, unhusked, green ears (Table 12).

In the production of whole or marketable green ears, husked or unhusked, it can be seen that the 'AG 1051 ' maize cultivar is the best for monocropping or for intercropping with the 'Corujinha' cultivar of the cowpea. As a monocrop producing pods or green grain, it is unimportant whether the cowpea cultivars 'Corujinha' or 'Sempre Verde' are used, since they did not differ in

Table 9 - Summary of the analysis of variance of the data for land equivalent ratio (LER) calculated from green-grain yield in cowpea cultivars and green-ear yield in maize cultivars ${ }^{1}$

\begin{tabular}{ccccc}
\hline \multirow{2}{*}{ Source of variation } & \multirow{2}{*}{ Degrees of freedom } & \multicolumn{3}{c}{ Green-pod weight (cowpea) } \\
\cline { 3 - 5 } & & Total & Mar weight (maize) \\
\cline { 3 - 5 } & 5 & $0.05^{\text {ns }}$ & $0.06^{\text {ns }}$ & $0.11^{\text {ns }}$ \\
Blocks & 3 & $0.03^{\text {ns }}$ & $0.03^{\text {ns }}$ & $0.03^{\text {ns }}$ \\
Treatments & 15 & 0.07 & 0.06 & 0.09 \\
Residual & &
\end{tabular}

1 n.s.; *: not significant; significant at $5 \%$ and significant at $1 \%$ probability respectively by F-test

Table 10 - Mean values for land equivalent ratio calculated from green-grain yield in cowpea cultivars and green-ear yield in maize cultivars $^{1}$

\begin{tabular}{ccccc}
\hline Cultivar & & \multicolumn{3}{c}{ Green-pod weight (cowpea) } \\
\hline \multirow{2}{*}{ Maize } & \multirow{2}{*}{ Cowpea } & Total & Marketable unhusked & Marketable husked \\
\cline { 3 - 5 } & & $1.26^{*}$ & $1.28^{*}$ & $1,26^{*}$ \\
AG 1051 & Corujinha & $1.16^{\mathrm{ns}}$ & $1.19^{\mathrm{ns}}$ & $1,14^{\mathrm{ns}}$ \\
AL Bandeirante & Corujinha & $1.12^{\mathrm{ns}}$ & $1.12^{\mathrm{ns}}$ & $1,11^{\mathrm{ns}}$ \\
AG 1051 & Sempre Verde & $1.13^{\mathrm{ns}}$ & $1,19^{\mathrm{ns}}$ \\
AL Bandeirante & Sempre Verde & $1.10^{\mathrm{ns}}$ & 21.29 & 25.40 \\
\hline Coefficient of variation $(\%)$ & & 22,58 & 29 &
\end{tabular}

${ }^{1 *},{ }^{\text {ns }}$ Mean values greater than or equal to 1.0 respectively, at $5 \%$ probability by t-test

Table 11 - Summary of the analysis of variance of the data for land equivalent ratio (LER) calculated based on green-grain yield in cowpea cultivars and green-ear yield in maize cultivars ${ }^{1}$

\begin{tabular}{ccccc}
\hline \multirow{2}{*}{ Source of variation } & \multirow{2}{*}{ Degrees of freedom } & \multicolumn{3}{c}{ Green-pod weight (cowpea) } \\
\cline { 3 - 5 } & & Total & Mar weight (maize) \\
\cline { 3 - 5 } & 5 & $0.11^{\mathrm{ns}}$ & $0.09^{\mathrm{ns}}$ & $0.12^{\mathrm{ns}}$ \\
Blocks & 3 & $0.05^{\mathrm{ns}}$ & $0.04^{\mathrm{ns}}$ & $0.03^{\mathrm{ns}}$ \\
Treatments & 15 & 0.08 & 0.08 & 0.11 \\
Residual & & & & \multicolumn{3}{c}{ Marketable unhusked } & Marketable husked \\
\hline
\end{tabular}

1 n.s.; *: not significant; significant at $5 \%$ and significant at $1 \%$ probability respectively by F-test 
Table 12 - Mean values for land equivalent ratio calculated from green-grain yield in cowpea cultivars and green-ear yield in maize cultivars $^{1}$

\begin{tabular}{ccccc}
\hline \multirow{2}{*}{ Source of variation } & \multirow{2}{*}{ Degrees of freedom } & \multicolumn{3}{c}{ Green-pod weight (cowpea) } \\
\cline { 3 - 5 } & & Total & Mar weight (maize) \\
\cline { 3 - 5 } & 5 & $0.11^{\mathrm{ns}}$ & $0.09^{\mathrm{ns}}$ & $0.12^{\mathrm{ns}}$ \\
\hline Blocks & 3 & $0.05^{\mathrm{ns}}$ & $0.04^{\mathrm{ns}}$ & $0.03^{\mathrm{ns}}$ \\
Treatments & 15 & 0.08 & 0.08 & 0.11 \\
Residual & 15 &
\end{tabular}

${ }^{1 *}{ }^{\mathrm{ns}}$ Mean values greater than or equal to 1.0 respectively, at $5 \%$ probability by t-test

pod or green-grain yield; however, when intercropping, 'Corujinha' would be the recommended cultivar.

The superiority of intercrops over monocrops may be due to a reduction in competition, and to facilitation between the crops involved (SILVA; SILVA, 2014). A reduction in competition can occur spatially through stratification of the foliage or roots, and temporally due to phenological differences. In the experiment on which the present study was based, it was seen that flowering in the two cowpea varieties occurred at the same time, and before flowering occurred in the two maize cultivars, which also coincided with the flowering season. Although the two cowpea cultivars are of indeterminate growth, it was found that the 'Corujinha' cultivar had a longer production period and invaded the maize more intensely than the respective production and invasion periods of the 'Sempre Verde' cultivar. It was also found that the 'AG 1051' cultivar had larger plants than 'AL Bandeirante' (data not shown). Larger maize plants would tolerate invasion more than would smaller plants, while at the same time favoring greater cowpea production, which would then have a better opportunity to intercept the solar radiation. These characteristics would favor the superiority of the AG 1051-Corujinha intercrop.

Facilitation results from improving environmental conditions, increasing the availability of resources, eliminating potential competitors, introducing beneficial organisms (mycorrhizae and others) or protecting against herbivores (SILVA; SILVA, 2014). In the present study, such aspects have not been evaluated, but several factors associated with facilitation have been verified by other authors. Greater water and nutrient availability were found in the maize-cowpea intercrops in relation to the monocrops (DAHMARDEH et al., 2010; GHANBARI et al., 2010; LATATI et al., 2014).

\section{CONCLUSIONS}

1. The 'AG 1051' maize cultivar was more productive than the 'AL Bandeirante' cultivar, both monocropped and intercropped. The cowpea cultivars showed similar performance under both cropping systems;

2. On average, the monocrops were superior to the intercrops in terms of green-ear, green-pod and greengrain yield;

3. If the aim is to produce green pods, intercropping is only beneficial when the 'AG 1051' maize cultivar is intercropped with the 'Corujnha' cultivar. If the aim is green-grain yield, intercropping remains advantageous when the 'AG 1051' maize cultivar is intercropped with either of the two cowpea cultivars;

4. The intercrop including the 'AL Bandeirante' maize cultivar is only beneficial when it includes the 'Corujinha' cultivar, and if the aim is to market husked, green ears of maize.

\section{REFERENCES}

ADAMS, M. W. Basis of yield component compensation in crop plants with special reference to the field beans, Phaseolus vulgaris. Crop Science, v. 2, p. 505-510, 1967.

ALMEIDA, I. P. C. et al. Baby maize, green ear, and grain yield of maize cultivars. Horticultura Brasileira, v. 23, p. 960-964, 2005.

ALMEIDA, M. F. Caracterização agrometeorológica do município de Marabá/PA. Marabá: Universidade Federal do Pará. Colegiado de Ciências Agrárias, 2007. 77 f.

ALVES, C. S. L. P. et al. Adaptabilidade de diferentes cultivares de milho submetidas às condições climáticas do Nordeste do Pará. Agroecossistemas, v. 9, p. 2-18, 2017.

ANDRADE, F. N. et al. Estimativas de parâmetros genéticos em genótipos de feijão-caupi avaliados para feijão fresco. Revista Ciência Agronômica, v. 41, p. 253-258, 2010.

BASTOS, E. A. et al. Parâmetros fisiológicos e produtividade de grãos verdes de feijão-caupi sob déficit hídrico. Water Resources and Irrigation Management, v. 1, p. 31-37, 2012.

BEDOUSSAC, L. et al. Ecological principles underlying the increase of productivity achieved by cereal-grain legume 
intercrops in organic farming: a review. Agronomy for Sustainable Development, v. 35, p. 911-935, 2015.

CASTRO, R. S.; SILVA, P. S. L.; CARDOSO, M. J. Baby maize, green maize, and dry maize yield of maize cultivars. Horticultura Brasileira, v. 31, p. 100-105, 2013.

COUTINHO, P. W. R. et al. Doses de fósforo na cultura do feijão-caupi na região nordeste do Estado do Pará. Revista Agro@mbiente On-line, v. 8, p. 66-73, 2014.

CRUZ, J. C.; PEREIRA FILHO, I. A. Cultivares de milho disponíveis no mercado de sementes do Brasil para a safra 2005/06. Sete Lagoas: Embrapa Milho e Sorgo, 2005. 24 p.

DAHMARDEH, M. et al. The role of intercropping maize (Zea mays L.) and cowpea (Vigna unguiculata L.) on yield and soil chemical properties. African Journal of Agricultural Research, v. 5, p. 631-636, 2010

EMPRESA BRASILEIRA DE PESQUISA AGROPECUÁRIA. Centro Nacional de Pesquisa do Solo. Sistema brasileiro de classificação de solos. Brasília: Serviço de Produção de Informação, 2013. 353 p.

FREIRE FILHO, F. (ed.). Feijão-caupi no Brasil: produção, melhoramento genético, avanços e desafios. Teresina: Embrapa Meio-Norte, 2011. 84 p.

GHANBARI, A. et al. Effect of maize (Zea mays L.) - cowpea (Vigna unguiculata L.) intercropping on light distribution, soil temperature and soil moisture in arid environment. Journal of Food Agriculture \& Environment, v. 8, p. 102-108, 2010.

GUEDES, R. E. et al. Consórcios de caupi e milho em cultivo orgânico para produção de grãos e espigas verdes. Horticultura Brasileira, v. 28, p. 174-177, 2010.

LATATI, M. et al. The intercropping cowpea-maize improves soil phosphorus availability and maize yields in an alkaline soil. Plant and Soil, v. 385, p. 181-191, 2014.

LV, Y. et al. Maize: soybean intercropping interactions above and below ground. Crop Science, v. 54, p. 914-919, 2014

LYNCH, J. P. Steep, cheap and deep: an ideotype to optimize water and $\mathrm{N}$ acquisition by maize root systems. Annals of Botany, v. 112, p. 347-357, 2013.

MEAD, R.; WILLEY, R. W. The concept of a Land Equivalent Ratio and advantages in yield from Inter-cropping. Experimental Agriculture, v. 16, p. 217- 218, 1980.
MI, G. et al. Ideotype root architecture for efficient nitrogen acquisition by maize in intensive cropping systems. Science China, v. 53, p. 1369-1373, 2010.

MÔRO, G. V.; FRITSCHE-NETO, R. Importância e usos do milho no Brasil. In: GALVÃO, J. C. C.; BORÉM, A.; PIMENTEL, M. A. Milho: do plantio à colheita. Viçosa, MG: UFV, 2015. 351 p. cap. 1, p. 9-25.

NDAKIDEMI, P. A.; DAKORA, F. D. Yield components of nodulated cowpea (Vigna unguiculata) and maize (Zea mays) plants grown with exogenous phosphorus in different cropping systems. Australian Journal of Experimental Agriculture, v. 47, p. 583-589, 2007.

QI, R. et al. Optimization of source-sink dynamics in plant growth for ideotype breeding: a case study on maize. Computers and Electronics in Agriculture, v. 71, p. 96$105,2010$.

SANTOS, E. R. et al. Consorciação de milho e feijão-caupi para produção de espigas verdes e grãos verdes em Tocantins. Nucleus, v. 11, p. 291-295, 2014.

SILVA, E. F. et al. Avaliação de cultivares de feijão-caupi irrigado para produção de grãos verdes em Serra Talhada-PE. Revista Caatinga, v. 26, p. 21-26, 2013.

SILVA, P. S. L. Consorciação milho e feijão-caupi para produção de espigas verdes e grãos verdes. Horticultura Brasileira, v. 19, p. 4-10, 2001.

SILVA, P. S. L.; SILVA, P. I. B. Consórcio de culturas como opção de aumento de produtividade no semiárido. In: VIDAL, R. A (org.). Interações positivas entre plantas que aumentam a produtividade. Porto Alegre: EVANGRAF, 2014. cap. 5, p. 62-84. $174 \mathrm{p}$.

SOUZA, F. R. S. et al. Produtividade e estabilidade fenotípica de cultivares de milho em três municípios do Estado do Pará. Pesquisa Agropecuária Brasileira, v. 37, p. 1269-1274, 2002.

SOUZA, P. J. O. P. et al. Cowpea leaf area, biomass production and productivity under different water regimes in Castanhal, Pará, Brazil. Revista Caatinga, v. 30, p. 748-759, 2017.

TAVARES, A. L. et al. Climate indicators for a watershed in the Eastern Amazon. Revista Brasileira de Climatologia, v. 23, p. 389410,2018 